\title{
Self-esteem in One's Abilities: Evidence from Private Sector Educational Institutes
}

\author{
Muhammad Naeem Shahid ${ }^{* 1}$, Muhammad Asim Sarwar ${ }^{2}$, Ayesha Ateeq $^{3}$, Aamir Abbas $^{4}$ \\ ${ }^{1}$ Assistant Professor, School of Management Studies, The University of Faisalabad, Pakistan \\ ${ }^{2}$ Lecturer, School of Management Studies, The University of Faisalabad, Pakistan \\ ${ }^{3}$ Lecture, Department of Banking and Finance, Government College University \\ ${ }^{4}$ Visiting Lecturer, School of Management Studies, The University of Faisalabad \\ *Corresponding author: naeem.shahid@tuf.edu.pk, naeemtuf@yahoo.com
}

\begin{abstract}
The study aims to examine the self-esteem level in private college teachers (permanent or visiting) of district Faisalabad, Pakistan. To accomplish the purpose of the study 100 questionnaire were sent to 5 well known private educational institutions of city Faisalabad, Pakistan. The results from the study indicates that symbolic variations are there in level of self-esteem between permanent and visiting faculty members of private colleges. This study also shows that permanent faculty members have high self-esteem as compared to visiting faculty members. They scored more on satisfaction, ability to do things.
\end{abstract}

ARTICLE INFORMATION

Received: $\quad$ March 2018

Revised: July 2018

Accepted: October 2018

DOI:

10.31580/jmis.v1i1.141

\section{INTRODUCTION}

Nature of job affects the personalities of human beings. In the developing countries, like ours, where people come out for the sake of earning money, they have to face certain other factors besides their jobs which affect their personalities. The paper intends to evaluate the level of self-esteem among teachers (visiting and permanent) of private colleges. The main purpose behind evaluating the self-esteems of visiting and permanent college teachers and know the reason/factors which cause variations in the level of their self-esteem.

According to Latif et al. (2011) high profile, well known and shining teaching staff is required by successful and famous educational system. The responsibility of teachers is of huge significance as they employ the most helpful teaching and educational skills to prosper specially in the practical life. High profile teachers and educational system in historical perspective have been very necessary part of the different civilization of the world. So teacher's self-esteem level regarding their duties is very essential to study.

The term self-esteem is most commonly used to check the psychological state of a person. According to Smith \& Mackie (2007) what we think about self is known as self-concept, positive and negative interpretation of the self is self-esteem, like how we feel. The same was described by Erkut (2006) that self-esteem is normally described as the self-evaluation; it is an adequate reply to one's selfdefinition. The appraisal point out to understanding of one's value and what is being examined is one's impression of who one is, or one's concept of itself. In every day terms, self-esteem can be defined as I like who I am, I don't like, or around these two end points. Singh \& kaur (2008) said thFigure 1at decisive attitude towards anyone's selfconcept is self-confidence and a trait of anticipated self. It indicates to a person's perceived ability to handle situation well without depending on others and to have positive self-evaluation.
The teachers are perceived as the most passionate representative of a community due to their productive performance. So for teachers, it is necessary to repeatedly evaluate their professionalism in order to hike supremacy in the ability of their teaching. Fulfilling all these make them devoted, faithful and above all of them professionals. Indeed the thought of the self-esteem in professionals injects them with the professionalism. The significance of self-esteem among professionals cannot be denied and in order to establish professionalism among them, professional of almost all the fields need to nurture the sensitivity of professional self-esteem. It absolutely empowers them to recognize their abilities, evaluate their personal importance and shape themselves so they may practice and deliver in their best. According to Cherry (2010) Self-esteem is used to portray a person's comprehensive sense of personal value. It is usually taken as a personality attribute that means it tends to be enduring and solid. Self-esteem involves a diversity of beliefs about self, like evaluation of one's own appearance, behavior and emotions. Dictionary (2012) the self-esteem is belief and confidence in your own ability and value.

The purpose of study is to depict a contrast of the self-esteem of permanent and visiting faculty members of private colleges in city district Faisalabad Pakistan.

\section{LITERATURE REVIEW}

According to Branden (1994) self-esteem has deep consequences for every form of our existence. Roy F. et al (2003) state that People high in self-esteem claim to be more likable and attractive, to have better relationships, and to make better impressions on others than people with low self-esteem.

The study is aimed to check the level of self-esteem in teachers. Every educational institution should provide teachers a well-balanced working environment to enhance their capabilities, growth and level of self-esteem. Alpay (2010) identify that qualities hidden under good 
counseling skills are easily identified with high self-esteem. One indication here that complete education sector has a duty in giving teacher an encouraging working environment and opportunities for their growth, certainly if this is fairly reflected in student accomplishment.

A teacher should also have a well-balanced level of self-esteem in his or herself as he or she is a role model for their students. While they are teaching, students always try to adapt many characteristics of their teachers. Loomans \& Loomans (1994) says combination of spiritual, social, psycological, physical and growth is learning. In every field of this process there is the potential to damage, keep or boost self esteemS. Teachers evaluation apparently influence learners success.

There is vigorous relationship between self-esteem and type/situation of job. The permanent status of teachers raise confidence and self-esteem, because when they know they are stable in their work, especially with confirmed amount of salary then no doubt they will feel relax. Getting a permanent status in the job increases teachers' selfworth. They realize that they are competent and they have some value and respect and no one under them are able to put them at a side. When they get confidence over their abilities then not only they remain alive but also reach the levels of success. This type of argument has been proposed by Kirkpatrick \& Ellis (2001). They display their opinions within the framework, even if various frameworks possibly also work. Their objective was that correct knowledge of self can save reasonable energy and time.

But when a teacher realizes that his or her job is not permanent and he or she is not the eternal part of the job, then unwillingly his or her sense of self-esteem lessens. The fear of being fired away on any basis gets on teaches' confidence and he or she starts to perceive his or her quality negatively and discourages him/herself. Davis (1988) said that virtually every social problem can be traced to people's lack of selflove. Twenge \& Campbell (2001) said that in fact, levels of self-esteem expanded when the confidence development moaned about the absence of self-esteem. Disturbingly, academic performance diminished in the meantime.

According to Swann, Stein \& Giesler (1992) the craving to feel good about self is perhaps not the only self related feeling at play. To confront the reality, people are inspired to anticipate themselves precisely and accept awareness of their unsatisfactory characteristics. Sedikides (1993) contribute that yet people learn positive things about their self then negative things. Despite the fact they may want to know if they are good or not, they choose to learn that they are good.

Some studies suggest that people with low self-esteem engage in more offending attitude afterwards (at least, by results of their report), whereas results of some other research have shown no effect of it. Whereas, one previous research by Trzesniewski et al. (2002) give exceptional indication that low self-esteem drives to misbehavior.

\section{METHODOLOGY}

The main objective of this research is to analyze the level of selfesteem among college teachers of district Faisalabad. The research is further intended to check which one of permanent and visiting faculty possesses high level of self-esteem.

Lecturer from 5 renowned private institutes, assistant professors, associate professors and professors are taken as sample in this study. To accomplish the purpose of this research 100 surveys were sent (through questionnaires) to 5 well known private educational institutions of city Faisalabad. The data were collected from Informatics College, tips college, Punjab College of information technology, IMIT College and superior college Faisalabad. 20 questionnaires were sent to each college, 10 were filled by permanent faculty and 10 were filled by visiting faculty members of each 5 college. The respondents were off age 20 to 60 years. All the surveys come back that shows $100 \%$ response. To achieve objectives, questionnaire was divided into two sections. First section covered demographic variables, second section comprised of Rosenberg SelfEsteem Scale

Rosenberg (1965) developed a ten item Likert scale with items answered on a four point scale - from strongly agree to strongly disagree. The original sample for which the scale was developed consisted of 5,024 High School Juniors and seniors from 10 randomly selected schools in New York State. Directions were given to respondents that there's a list of information dealing with your natural feelings about yourself. In case if you are strongly agree with this, circle SA. In case of agree then, circle A. If you don't agree, circle D. If you strongly disagree, circle $\mathrm{SD}$. And Scoring was $\mathrm{SA}=4, \mathrm{~A}=3, \mathrm{D}=2$, $\mathrm{SD}=1$. The data was analyzed through SPSS v. 19.

\section{SAMPLE CHARACTERISTICS}

Table 1 shows respondents in accordance with gender, age, marital status, length of service, organizational hierarchy, job nature, educational background and publications. By and large $71 \%$ respondents are male and $29 \%$ are female. Mostly are below 35 years. Most of the teachers are having 5 years of experience in their current institutions. 52\% respondents having masters level of education, $44 \%$ having MS and $4 \%$ having Ph.D. $62 \%$ respondents are lecturers, $18 \%$ are assistant professors, $11 \%$ are associate professor and $9 \%$ are professors. All they belong to different disciplines like science, arts, commerce, IT, social sciences and business management. Out of 100 respondents, $50 \%$ respondents are the permanent part of the institution and $50 \%$ are visiting faculty members. Finally $44 \%$ respondents have their research publications while $56 \%$ yet have no publication.

\section{GENERAL FINDINGS}

The table \# 2 shows that permanent faculty members are more satisfied (Mean $=1.8400)$ with themselves as compared to visiting faculty members (Mean $=1.6400)$. Whereas there is a significant difference between the satisfaction level of permanent faculty members and visiting faculty members as $t$-value is significant $(p=0.017)$. Visiting faculty members show that they think they are not good at all $($ Mean $=1.9800)$ while permanent faculty members think in different way having mean value of 1.7600 . This difference is statistically significant $(\mathrm{p}=0.029)$

With the mean value of 1.600 permanent faculty members show that they have number of good qualities while visiting faculty members $($ Mean $=1.5200)$ believe that they have less number of good qualities.

Table 1. Mean Values of each item

\begin{tabular}{|c|c|c|c|c|c|c|}
\hline & $\begin{array}{l}\text { Nature } \\
\text { of Job }\end{array}$ & $\mathbf{N}$ & $\begin{array}{l}\text { Mea } \\
\mathrm{n}\end{array}$ & $\begin{array}{l}\text { t- } \\
\text { statisti } \\
\text { c }\end{array}$ & $\begin{array}{l}\text { F- } \\
\text { statistic }\end{array}$ & $\begin{array}{l}\mathrm{p}- \\
\text { values }\end{array}$ \\
\hline $\begin{array}{l}\text { On the } \\
\text { whole, I } \\
\text { am }\end{array}$ & $\begin{array}{l}\text { Permane } \\
\text { nt }\end{array}$ & $\begin{array}{l}5 \\
0\end{array}$ & 1.66 & \multirow[t]{2}{*}{-1.2} & \multirow[t]{2}{*}{5.896} & \multirow[t]{2}{*}{0.017} \\
\hline $\begin{array}{l}\text { satisfie } \\
\text { d with } \\
\text { myself. }\end{array}$ & Visiting & $\begin{array}{l}5 \\
0\end{array}$ & 1.84 & & & \\
\hline $\begin{array}{l}\text { At } \\
\text { times, I } \\
\text { think }\end{array}$ & $\begin{array}{l}\text { Permane } \\
\text { nt }\end{array}$ & $\begin{array}{l}5 \\
0\end{array}$ & 1.98 & \multirow[t]{2}{*}{1.72} & \multirow[t]{2}{*}{1.06} & \multirow[t]{2}{*}{0.306} \\
\hline $\begin{array}{l}\text { am no } \\
\text { good at } \\
\text { all. }\end{array}$ & Visiting & $\begin{array}{l}5 \\
0\end{array}$ & 1.76 & & & \\
\hline that t & $\begin{array}{l}\text { Permane } \\
\text { nt }\end{array}$ & $\begin{array}{l}5 \\
0\end{array}$ & 1.6 & \multirow[t]{2}{*}{0.72} & \multirow[t]{2}{*}{2.453} & \multirow[t]{2}{*}{0.121} \\
\hline $\begin{array}{l}\text { have a } \\
\text { number } \\
\text { of good }\end{array}$ & Visiting & $\begin{array}{l}5 \\
0\end{array}$ & 1.52 & & & \\
\hline
\end{tabular}




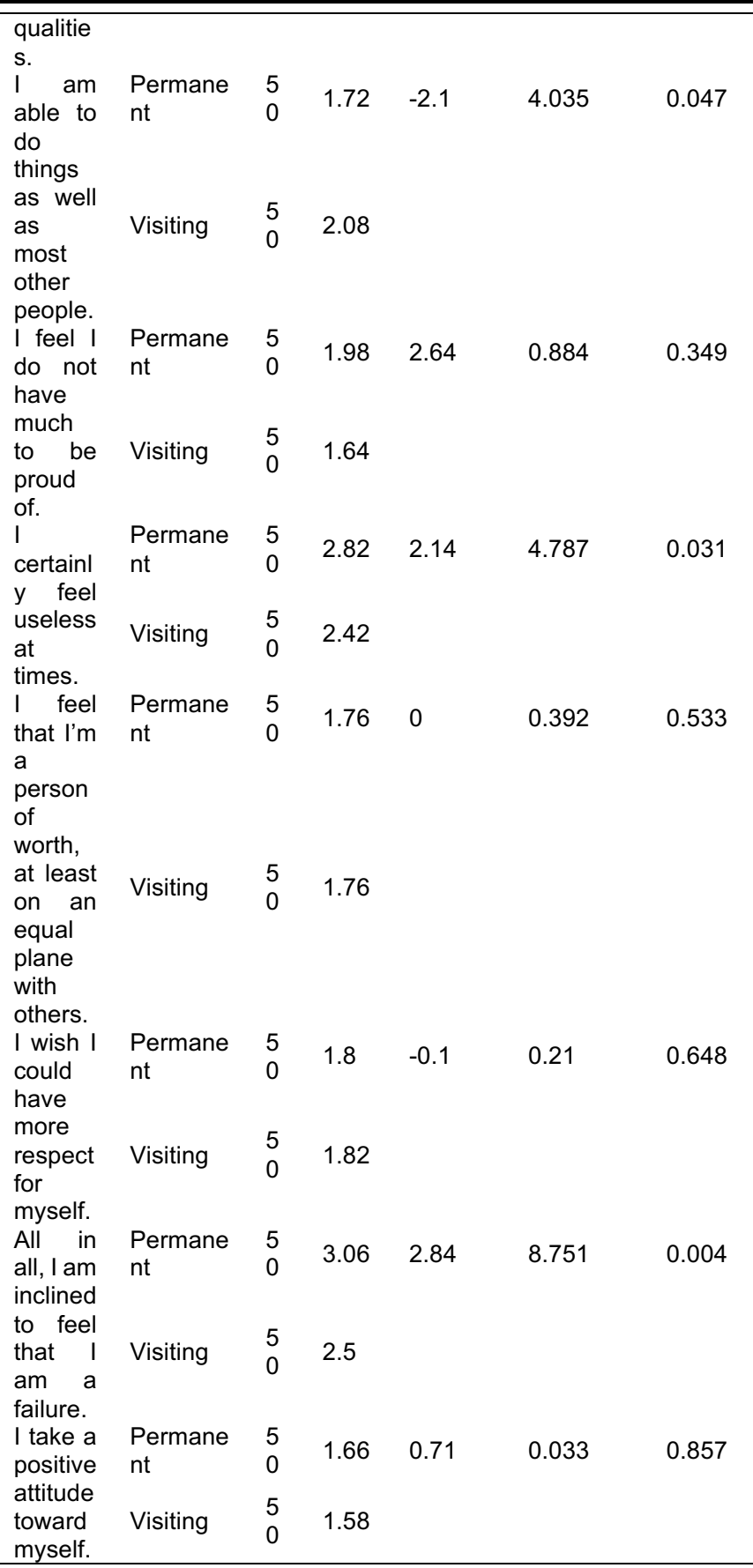

Permanent faculty members are more able to do things well (Mean $=2.0800)$ as compared to visiting faculty $($ Mean $=1.7200)$. Significant difference exists between permanent and visiting members in-ability to do things as $t$ value $(P=0.047)$. Visiting faculty members feel they do not have much to be proud of (Mean $=1.6400$ ) while with Mean value of 1.9800 , permanent faculty feels that they do have many things to be proud of but difference exist between them is significant $(\mathrm{p}=0.018)$.

With Mean value of 2.4200 visiting faculty members often feel useless at times while permanent usually do not feel whereas t-value is significant $(\mathrm{p}=0.031)$.

Results showing that permanent faculty members feel that they are the person of worth (Mean $=1.7600)$ similar results are found for visiting faculty members and the difference between them is not significant.

Both permanent and visiting faculty members wish that they could have more self-respect, the Mean value for both are showing the same result Mean $=1.8200$ and the difference between them is not significant.

Visiting faculty member with mean value 3.060 showing that they are more inclined to feel that they are failure as compared to permanent faculty members Mean=2.5000 also showing a significant result with $t$ value $(p=0.0040)$

The results show that permanent faculty members having positive attitude towards their self, (mean value 1.6600) whereas visiting faculty members are showing different results and their mean value is 1.5800 which is statistically different from permanent faculty members.

\section{CONCLUSION}

The result of the study shows that permanent teachers have high self-esteem than visiting faculty members. Self-esteem is not just boast about yourself, apparently is about knowing within, that you are desirable among the best. Believing on yourself and loving yourself the way you are. You are perfect it is not about that. High self-esteem of teachers is essential for their effective role in education. Having a good self-esteem helps teachers to feel good about their self and everything they do while they are teaching and encourages them to give new ideas to their students for their career developments and achievements. Whereas low self-esteem does not show that you don't have a good viewpoint about yourself which but it causes depression and many other problems like job stress and dissatisfaction in teachers. So low level of self-esteem contributes to low performance of organization, low performance of teachers' overall, low standards of work, high staff downsizing, and increases ratio of absenteeism of staff due to problems of health such as depression, anxiety, headache and back pain.

\section{References}

Alpay, E. (2000). Self-concept and self-esteem. London: The Department of Chemical Engineering and Chemical Technology, Imperial College of Science, Technology, and Medicine.

Branden, N. (1994). The six pillars of self-esteem. Bantam Books.

Davis, I. (1988). Ministry for feeling good. London Times.

Dictionary, C. (2012). Bitish English dictionary.cambridge.org. Retrieved December 12, 2012, from dictionary.cambridge: dictionary.cambridge.org/dictionary/british/self-esteemShare.

Smith, E. R., \& Mackie, D. M. (2007). Social Psychology. New York: Psychology Press.

Erkut, S. (2006). The Definition of Self-esteem. Wellesley Centers for Women: www.wcwonline.org.

Latif, K., Shahid, M. N., Sohail, N., \& Shahbaz, M. (2011). Job satisfaction among public and private college teachers of District Faisalabad, Pakistan: A comparative analysis. Interdisciplinary Journal of Contemporary Research in Business, 3(8), 235-242.

Kirkpatrick, L. A., \& Ellis, B. J. (2001). An Evolutionary-Psychological Approach to Self-esteem: Multiple Domains and Multiple Functions. Blackwell handbook of social psychology: Interpersonal processes, 409-436.

Loomans, D., \& Loomans, J. (1994). Full esteem ahead: 100 ways to build selfesteem in children and adults. HJ Kramer.

Rosenberg, M. (1965). Society and the Adolescent Self-Image. Princeton.

Sedikides, C. (1993). Assessment, enhancement, and verification determinants of the self-evaluation process. Journal of personality and social psychology, 65(2), 317.

Singh, T., \& Kaur, P. (2008). Effect of meditation on self confidence of studentteachers in relation to gender and religion. Journal of exercise science and physiotherapy, 4(1), 35-43.

Swann, W. B., Stein-Seroussi, A., \& Giesler, R. B. (1992). Why people selfverify. Journal of personality and social psychology, 62(3), 392.

Trzesniewski, K. H., Donnellan, M. B., Robins, R. W., Moffitt, T. E., \& Caspi, A. (2002). Do juvenile delinquents have high or low self-esteem. In annual meeting of the Society for Personality and Social Psychology, Savannah, GA

Twenge, J. M., \& Campbell, W. K. (2001). Age and birth cohort differences in self-esteem: A cross-temporal meta-analysis. Personality and Social Psychology Review, 5(4), 321-344. 